\title{
The Development of Regional-Head Election Concept without Suspect
}

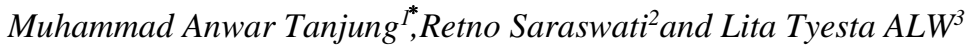 \\ 1 LPDP and Faculty of Law, Diponegoro University, Semarang, Central Java, Indonesia. \\ 2 Professor of Constitutional Law, Faculty of Law, Diponegoro University.Indonesia \\ 3. Doctor of Constitutional Law, Faculty of Law, Diponegoro University.
}

\begin{abstract}
Election of regional-head candidates without suspect as choosing leaders with integrity and quality as well as without legal problems is a realization of democratic election. Empirical facts show that 2018 regionalhead election involves some regional heads identified as suspects. Laws needs to be able to answer such facts. Therefore, this study investigates the legal framework of regional-head candidates' requirements and the development of legal concept of regional-head election without suspect. This study is normative juridical, and secondary legal sources is employed. This study contributes to the development of legal concept of regional-head election without suspect in holding the upcoming 2022 regional-head elections.
\end{abstract}

\section{Introduction}

Values lying in Pancasila as the basic philosophy of the state [1] need to be implemented in and guaranteed by the Unitary State of the Republic of Indonesia. The guarantee is realized through the fact all citizens have equal positions within the law and government as well as uphold the law and government without exception [2].It means that every citizen has equal rights protected by law and government. Indonesia does not recognize life stratification. In other words, there are no citizens of class 1 or class 2 , so this is what justice stands for. Consequently, each Indonesian citizen deserves equal rights to serve as the president of Indonesia.Within the context of this study, every citizen deserves to be elected as the candidate of regional head without exception.

The 2018 regional-head election, in fact, involves some regional-head candidates who are identified as suspects. The citizens seem to be confused about the issue. The debate is no longer productive, and the democracy is directed to contradict human rights by some elite. Democracy essentially guarantees human rights, and conversely guarantee for human rights characterizes democracy.

With regard to that view, there is a need to formulate legal concept of regional-head election without suspect in order to choose the best leaders who bring prosperity for the development of regional and national economy in general.

\footnotetext{
* Corresponding author: 99tanjunganwar@gmail.com
} 


\section{Objective of The Study}

Law is established for society, and it cannot be conversely changed. The existence of law, thus, functions to serve and protect society. Law is considered as an institution aiming to take society to fair and prosper life and to make them happy [3].Realizing legal state of Indonesia, according to Satjipto Rahardjo, is to undertake conscience state activities, so every actor in the state positions is required to understand what concerns in the state underlying in the duties. There is important moral value and commitment that need to be realized - creating and developing "a country that delights the people [4]."The statement prompts worries over the candidates of regional head alleged to have legal problems. According to this fact, this study proposes a concept of regional-head election without suspect with the following research problems:

1. How is legal framework of regional-head candidates' requirements established?

2. How is the legal framework of regional-head election without suspect developed?

\section{Methodology}

This study is normative juridical research by using qualitative method [5]. This study used secondary data which was in the form of literature of primary and secondary legal sources. This study also employed two approaches: statute and conceptual approach. Statute approach is an approach applied to various regulations related to general election as well as the others related to the object of the study. Conceptual approach, moreover, is used to comprehend the concept of democratic regional-head election. The data is obtained from documentary study, and the data is then inventoried and systematized to be investigated and analyzed to answer the research problems.

\section{Discussion}

\section{a. Legal Framework of Regional-Head Candidates' Requirements}

Every person has equal rights to take part in government of the state, directly or through freely chosen representatives [6].In the article 28D paragraph (3) of the Constitution of the Republic of Indonesia, it is stated that every citizen deserves equal chance in government. According to the statement, it is also asserted in the regulations of governor, regent, and mayor elections that every citizen deserves to get equal opportunity to nominate themselves and to be promoted as the candidates of governor and vice-governor, regent and vice-regent, as well as mayor and vice mayor.

Requirements needed to be promoted as the candidates of governor and vice-governor, regent and vice-regent, as well as mayor and vice mayor are regulated in the article 7 paragraph (2).In the concerned article, there is no point stating that suspects are not allowed to be promoted as the candidate of regional head. Furthermore, general election organizers have attributive authority to undertake the law number 10 of 2016. General Election Commission (KPU) establishes KPU regulation number 3 of 2017 on the candidacy of governor and vice-governor, regent and vice-regent, as well as mayor and vice mayor. Article 4 paragraph (1) and (2) of a quo regulation consistently with the law does not prevent every citizen identified as suspect to promote himself/herself as the candidate of regional head.

Changes can be carried out by the time the candidates are set, and it can only be undertaken by political parties, coalition of political parties, or individual candidate due to several reasons:

a. unqualified in term of health; 
b. permanently unavailable; or

c. criminally liable under court's decision with permanent legal force.

Permanently unavailable conditions include the following terms:

a. passing away; atau

b. permanently unable to carry out duties.

Empirical facts show that some candidates of regional heads are identified as suspects by Corruption Eradication Commission (KPK). The legal framework, in fact, does not provide the choice in which the regional heads identified as suspect are eliminated in the candidacy. In this case, a principle of criminal law, presumption of innocence, is applied [7].Presumption of innocence principle is explained in the general description of the criminal law procedure code (KUHAP) point 3 of c - "every person suspected, arrested, prosecuted, or brought to court must be considered innocent until the court decision declares wrongdoing and obtains permanent legal force". In the law number 48 of 2009, article 8 paragraph (1), it is affirmed that every person suspected, arrested, prosecuted, or brought to court must be considered innocent until the court decision declares wrongdoing and obtains permanent legal force.

Yahya Harahap asserts that the suspects should be considered as a person with dignity. They need to be judged as subject, not object. The one investigated is not a suspect - the crime becomes the object of investigation, and the investigation is directed to the crime committed. The suspects need to be considered innocent based on presumption of innocence principle until court decision which has permanent legal force is achieved[8]. Andi Hamzah specifically contends presumption of innocent is suspects' right given as human - including the right to take part in election.

Legal framework needs to consistently guarantee that condition as it is included as human rights that have to be protected. Human rights are a set of rights underlying in the human existence as God's creature, and they are also God's graces that must be respected, upheld, and protected by legal state, government, and everyone for honor and protection of human's dignity and prestige.

Article 25 of the International Agreement on Civils' Rights and Political Rights on 1960 states that every citizen has equal rights and chances, without exception, to elect and to be elected in regular general election carried out with equal suffrage and confidential ballots guaranteeing the electors' choice independently.

Indonesia, as a member of the United Nations, has moral and legal responsibilities to uphold and realize Universal Declaration of Human Rights established by the United Nations as well as various instruments received by the Republic of Indonesia as stipulated in the law number 39 of 2009 on human rights.

The members of the declaration respect their citizens' rights to actively take part in the state government directly or through the representatives chosen freely in fair election process. That becomes the state's responsibility to defend and protect human rights based on the law and responsibilities of international human rights.

\section{b. Development of Legal Concept of the Election of Regional Heads without Suspect}

The main principles that can be used in establishing electoral laws are [9]:

- Electoral laws must be stipulated in unambiguous and clear language.

- Electoral laws must avoid contradictive terms dealing the law regulating national-level election, sub-national level (province or state) election, and local general election; the terms regulating national election administration have to be correspond to the other terms as court's decision in particular level can prevail legislation in other legal jurisdictions. 
- Every authority and responsibility of national and local election organizers as well as government must be clearly stated, classified, and described in order to avoid contradiction or overlapping of power held by other agencies.

- Electoral laws must be established in advance from the election date to provide political participants and voters with sufficient time to comprehend the rules and process of general election. Electoral laws applied in the last minutes tend to minimize the legitimacy and legal credibility as well as to prevent the political parties and voters to get information about the rules of election process on time.

- Electoral laws must be enacted in accordance with the applicable laws governing the dissemination of legislation by the legislature. Electoral laws that are not enacted in accordance with applicable law can be challenged and invite the risk of being voided by the court.

- Electoral law must be published and provided for the users including general public.

Juridical arguments do not allow to abort the candidates for regional heads who are competing. The empirical fact that people are willing to hold regional-head election without suspect needs to be realized. People begin to think of the appropriate legal constructs for that, and the most immediate solution is undertaken through government regulation in lieu of law (Perppu).

Article 22 states, "In the case of the crunch that compels the President to be entitled to issue government regulation in lieu of law, the government regulation must be approved by the House of Representative in the following trial. If it is not, then the government regulation must be revoked. "The President has the right to enact the regulation and to declare a state of danger and emergency [10].The objective of the establishment of Perppu is to anticipate "critical and coercive" situations. Thus, there is acoercion of the situation to be immediately anticipated, but it is still in the legal corridor through Perppu.It must be also discussed in the next trial to be approved or to be rejected as law [11].

Citing Nikmatul Huda's argument, government regulation in lieu of law is established in the corridor of law. Dismissing candidates of regional head identified as suspect not only contradicts the principle of presumption of innocence but also violates human rights. The possibility of being rejected by the House of Representative can happen, and the possibility of being accepted and established as law are likely to be reached in order to be tested in the Constitutional Court.

Making amendment to electoral laws of regional heads is issued, as well. However, it is less likely to carry out because election works are scheduled. All of the processes have been structured from the beginning to the end of the election. Legal framework regulates effective mechanism and legal settlements for the sake of compliance with laws [12].This becomes the principle in realizing democratic election. The amendment will take time, and consequently can delay the vote as replacing the candidate requires long process, as well. The possibility to have juridical review of the Constitutional Court to the changes of a quo might happen and take time.

A solution then arises which aims to revise KPU Regulation number 3 of 2017 on the candidacy of the election of governor and vice-governor, regent and vice-regent, and/or mayor and vice-mayor. This solution is considered more difficult to be implemented. There is a possibility that such solution will be challenged by the candidates identified as suspects to the Election Supervisory Agency(Bawaslu) for allegedly committing administrative violations. The consistency of KPU regulations must be borne in mind in order to achieve the objectives of a quo law. Rule enforcement must not contain any claim that exceeds what law is able to carry out or regulate [13].Lex Superior Derogate Legi Inferiori, in which the higher legislation outweighs the lower legislation, is a legal principle that must be obeyed by the legislators. 
Bringing future regional heads with integrity and quality is the responsibility of all citizens. The best thing that can be done is to make the election organizers transparent. Transparency is the basic standard for every activity carried out by election organizers. Implementing transparency can help the election organizers to reduce the perception of doing corruption and identify electoral violations [14].

Election organizers need to publicly reveal the fact that some candidates are identified as suspects through socialization and press release. However, at the same time voters are still allowed to choose the candidate. Choosing is a matter of conscience and logic. The election organizers' responsibility is only to reveal openly because transparency is the principle of realizing democratic election.

Conducting education program for voters in implementing regional-head election is required. One of the functions of election is a means of political education. General election is one form of political educations which is considered direct, open and mass and is expected to increase political understanding and raise public awareness of democracy[15].This can be done by all stakeholders such as election organizers, observers groups, political parties, or other groups. Education for the voters is a joint effort to elect leaders with integrity and quality. The community expect the funds used to organize elections can be wisely and efficiently spent for such activities as realizing education for voters and information dissemination.

Political parties hold significant role to determine the candidates of regional heads with integrity and quality in the election of regional head. Political parties publish and promote their programs as well as propose candidates to compete in the election. According to Mackanzie, there are four conditions for realizing sustainable democratic and institutional election[16]:

1. There is independent court integrating electoral regulation;

2. There is fair, competent, and non-partisan administrative agency to hold election;

3. There is development of the organized party system to establish a leader and policies among the alternatives of the chosen policies;

4. There is acceptance from political communities over particular rules including the structures and limitations in obtaining authorities.

Political parties have some functions. First, they undertake recruitment of the future leaders. The chosen ones are the candidates who are eligible to win the election. Parties frequently recruit citizens with integrity and quality, who are eligible to nominate themselves. There are several things that need to be taken into consideration in the process of internal recruitment of the future leaders [17]:

1. Certification

This can be done by using electoral laws, party's regulation, and informal social norms defining criteria for eligible candidacy.

2. Nomination

This involves survey agencies on the selection and acceptance of the candidates in public before determining who is going to be nominated.

3. Election

This is the final process determining the candidates who are going to be nominated by party. The mechanism employed definitely reflects democratic election process.

By following those considerations, voters are given good choices, and the chosen leaders are eligible to govern and achieve strong legitimacy from the public. Second, political parties provide a mechanism for filtering modern political parties - eliminating ineligible or even corrupting candidates. Being candidates nominated by a one of the political parties is an important step in winning position in government. Political parties refuse to support weak prospective leaders and are reluctant to choose candidates with many deficiencies. In fact, the filtering mechanism is still imperfect. 
The legal framework must ensure that every political party and candidate is free to express opinions and deserves freedom of assembly, access to voters and all stakeholders in the electoral process, and equal chances of success,including candidates of regional head identified as suspect. Modern political parties must develop a system that is capable of producing candidates with integrity, professionalism, and quality.

\section{Conclusion}

Legal framework of regional-head candidates' requirements provides no opportunity in replacing the candidates identified as suspects. Democracy and human rights expect leaders with integrity, quality, and no involvement in legal issues. The development of legal concept of electing regional heads without suspect can be carried out by creating recruitment system of the candidates through modern political parties. There is a need to revise the law number 10 of 2016 by adding article 7 paragraph (2) point V stating that "track records of the candidates have been recognized by Corruption Eradication Commission (KPK) proved by the statement letter of the concerned political parties". Track records only function as consideration, and the consideration is only suggestion for political parties to nominate or eliminate the candidates in order to elect leaders with integrity, quality, and no involvement in legal issues. This is a realization of modern political parties in Indonesia, which are considered fair.The funding of political parties is charged to the state rationally by considering the state's financial capacity. Political parties should no longer receive donations from any party. Financial audits of political parties undertaken by independent institutions can be taken into account, as well.

\section{References}

1. S. Poespowardojo, Filsafat Pancasila Sebuah Pendekatan Socio-Budaya, (Penerbit PT. Gramedia Pustaka Utama, Jakarta, 1994).

2. Article number 27 paragraph (1) of the 1945 Constitution of Unitary Nation of the Republic of Indonesia.

3. S. Rahardjo, Hukum Progresif Sebuah Sintesa Hukum Indonesia, (Penerbit Genta Publishing, Yogyakarta, 2009).

4. S. Rahardjo, Negara Hukum yang Membahagiakan Rakyatnya, (Penerbit Genta Publising, Yogyakarta 2009).

5. L.J. Moleong, Metodologoi Penelitian Qualitatif, (Penerbit PT. Remaja Rosda Karya, Bandung, 2012).

6. Universal Declaration of Human Rights by United Nations in 1948, article 21.

7. J. A. Hamzah, Hukum Acara Pidana Indonesia edisi Kedua, (Penerbit, Sinar Grafika, Jakarta, 2008).

8. M. Y. Harahap, S.H. "Pembahasan Permasalahan Dan Penerapan KUHAP Penyidikan Dan Penuntutan”, (Penerbit, Sinar Grafika, Jakarta, 2000).

9. Global Commisions on Elections Democracy \& Security, Deepening Democracy A Strategy For Improving the Integrity Of Elections Worldwide, September 2012.

10. N. Huda, Politik Ketatanegaraan Indonesia, Cetakan Pertama,(FH UII Press, Yogyakarta, 2003).

11. N. Huda, Negara Hukum, Demokrasi dan Judicial Review, (UII Press, Yogyakarta, 2005).

12. IDEA, Desain Penyelengaraan Pemilihan umum, Buku Pedoman Internasional IDEA, Perludem, 2016.

13. E. Warassih, Pranata Hukum Sebuah Telaah Sosiologis, (Penerbit Suryandaru Utama, Malang, 2005). 
14. IDEA, Desain Penyelengaraan Pemilihan umum, Buku Pedoman Internasional IDEA, Perludem, 2016.

15. S. Pamungkas, Perihal Pemilu, (Penerbit Laboratorium Jurusan Pemerintahan Fisipol UGM, Yogyakarta, 2009).

16. S. Haris (ed), Menggugat Pemilu Orde Baru, (Penerbit Yayasan Obor Indonesia dan PPW-LIPI, Jakarta, 1998).

17. IDEA, Building political parties: Reforming legal regulations and internal rules, (Harvard University, Cambridge, 2005). 